\title{
RELATION BETWEEN BETA 2 MICROGLOBULIN LEVELS AND CARDIAC PERFORMANCE IN PATIENTS ON REGULAR HAEMODIALYSIS
}

\author{
By
Mohamed Fathy Al-Mshaly, Safwat Farrag Ahmed, Mohamed Saeed Al- Shorbagy*, El-Sayed Mohamed Rashed and Mohamed Ahmed Mosaad** \\ Departments of Internal Medicine \& Nephrology, Clinical Pathology* and Cardiology**, \\ Faculty of Medicine, Al-Azhar University \\ Corresponding author: Mohamed Fathy Al-Mshaly, \\ E-mail: mohamedfathy888@gmail.com
}

\begin{abstract}
Background: B2-microglobulin (B2M) is recognized as a surrogate marker of middle-molecule uraemic toxins and is a key component in the genesis of dialysis-associated amyloidosis.

Objectives: To investigate the relation between hidden cardiac dysfunction in one side and B2M levels, conventional risk factors low hemoglobin levels, and aging on the other side.

Subjects and methods: This was a case control study conducted on 50 patients aged 20-60 years with ESRD on regular HD and 50 apparently healthy individuals at El- Mokattam Insurance Hospital from September 2019 till March 2020.

Results: There were statistically significant differences between groups regarding B2M, EF, LVMI, intraventricular septal thickness and LVEDD.

There were no statistically significant differences between groups. Patient's B2- microglobulin in Group (A) ranged between 76.00-109.70 with mean \pm S.D. 94.162 \pm 9.735 , while in Group (B) ranged between 0.783.29 with mean \pm S.D. $1.956 \pm 0.704$. There were statistically significant differences between groups. Patient's LVMI in Group (A) ranged between 111.87-131.59 with mean \pm S.D. 123.41 \pm 5.675 , while in Group (B) ranged between $82.02-104.84$ with mean \pm S.D. $91.63 \pm 7.236$. There were statistically significant differences between groups. Patient's LVEDD in Group (A) ranged between 5.94-7.56 with mean \pm S.D. 6.79 \pm 0.505 , while in Group (B) ranged between 3.27-5.25 with mean \pm S.D. 4.25 \pm 0.571 . There were statistically significant differences between groups. Patient's LVESD in Group (A) ranged between 4.80-5.73 with mean \pm S.D. $5.34 \pm 0.250$, while in Group (B) ranged between 2.87-3.65 with mean \pm S.D. 3.27 \pm 0.243 . There were no statistically significant differences between groups.
\end{abstract}

Conclusion: Plasma B2M level was significantly and directly correlated with some cardiac performance factors such as LVMI, LVEDD, and LVESD. It was also significantly and inversely associated with GFR, albumin and $\mathrm{Hb}$.

Keywords: Beta-2 microglobulin, cardiovascular disease, chronic kidney disease, mortality, uremic toxins, haemodialysis. 


\section{INTRODUCTION}

Beta-2 microglobulin (B2M) is a lowmolecular-weight polypeptide (11800 Da), which is present on the surface of all nucleated cells, expressing the major histocompatibility class I. Under physiologic conditions, B2M is produced at a constant rate and is eliminated from circulation by kidneys. In patients with a range of inflammatory, hematologic, immunodeficiency, and renal diseases, plasma B2M levels are elevated (Jasim et al., 2019).

In patients with chronic kidney disease (CKD), plasma B2M levels are elevated, especially in patients on hemodialysis (HD) in whom glomerular filtration rate (GFR) is almost completely absent. B2M is also a surrogate marker of middlemolecular-weight uremic toxins in patients on HD, which is cleared only by high-flux membrane. In some studies, predialysis serum B2M level predicted mortality and increase of B2M clearance during HD was associated with improved outcomes. In addition, elevated plasma $\mathrm{B} 2 \mathrm{M}$ level is a potential risk factor for the development of dialysis-related amyloidosis (Wong et al., 2016).

B2-microglobulin (B2-m), the nonpolymorphic chain of the major histocompatibility Class I complex (MHC-I), is found on the surface of all nucleated cells and plays a central role in cellular immunology. Its synthesis rate normally ranges from $2-4 \mathrm{mg} / \mathrm{kg} /$ day with a half-life of 2-5 hours. In healthy individuals, the plasma concentration varies from 1 to $3 \mathrm{mg} / \mathrm{L}$ which varies inversely with the glomerular filtration rate (GFR). More than $95 \%$ of $32-\mathrm{m}$ is eliminated by degradation in the proximal tubule. Since this compound cannot be removed fromthe serum by the kidney or certain dialysis membranes in patients with renal dysfunction on dialysis, B2-m concentration is increased by up to 60 -fold in patients with end-stage renal disease (ESRD). Accumulations of $82-\mathrm{m}$ in these patients lead to Dialysis-Related Amyloidosis (DRA) (Hoang et al., 2019).

In general, it becomes apparent only after more than 5-7 years of renal replacement therapy. This type of amyloid may be seen even in patients with longstanding, severe renal failure who are not yet treated by dialysis or related procedures. 3 Age above 40- years at the start of dialysis, 4 duration of dialysis, 5 use of cuprophane and low-flux membranes and use of low purity dialysate are identifiable risk factors. B2m-related amyloid has a marked affinity for joint tissues (cartilage, capsule, synovium). The main signs and symptoms of DRA are musculoskeletal disorders such as carpal tunnel syndrome, joint arthro-pathy, and bone cysts leading occasionally to pathologic bone fractures (Singh et al., 2017).

It is still unclear whether B2M is an important factor of cardiovascular mortality in patients with CKD. In some clinical studies, B2M had an active role in vascular damage by up regulation of interleukin-1 (IL-1) and tumor necrosis factor $\alpha$ (TNF- $\alpha)$ expression. In addition, it might cause cardiovascular disease by amyloid formation. However, in the other studies, higher serum B2M levels were associated with better nutritional status and survival in patients with CKD (Fatima et al., 2018). 
The aim of this study was to investigate the relation between hidden cardiac dysfunction in one side and B2M levels, conventional risk factors low hemoglobin levels, and aging on the other side.

\section{PATIENTS AND METHODS}

This was a case control study conducted on 50 patients aged 20-60 years with ESRD on regular hemodialysis and 50 apparently healthy individual at ElMokattam Insurance Hospital from September 2019 till March 2020.

Target population: Fifty patients aged 20-60 years with ESRD on regular HD and 50 apparently healthy individuals matched for age and sex.

\section{Inclusion criteria:}

1. Patients with ESRD on regular HD for at least 3 months.

2. Informed consents from all individuals studied.

3. Age ranged from 20 to 60 years old.

\section{Exclusion criteria:}

1. Hospitalization due to non-renal causes.

2. Heart failure or any acute cardiac events within 3 months.

3. Ejection fraction less than $50 \%$.
4. Pregnancy.

5. Uncontrolled hypertension and Diabetics.

6. Malnutrition.

7. Active malignancy.

All individuals are subjected to clinical assessment and laboratory assessment.

Ethical committee: Permission from the Faculty of Medicine ethical committee was also obtained and approval from institutional review board was taken, with written consents from every subject sharing in this work.

\section{Statistical analysis:}

Analysis of data was done using Statistical Program for the Social Science version 20 (SPSSInc., Chicago, IL, USA). Quantitative variables were described in the form of mean and standard deviation. Qualitative variables were described as number and percent. In order to compare parametric quantitative variables between two groups, Student $t$ test was performed or Mann-Whitney test. Qualitative variables were compared using chi-square (X2) test or Fisher's exact test when frequencies were below five. Pearson correlation coefficients were used to assess the association between two normally distributed variables. $\mathrm{P}$ value < 0.05 was considered significant. 


\section{RESULTS}

Patients were classified into 2 groups: Group (A): 50 patients aged 20-60 years with ESRD on regular HD and Group (B): 50 apparently healthy individual matched for age and sex. Age in Group (A) ranged between 20-60 years with mean \pm S.D. $43.94 \pm 12.363$ years while in Group (B) was ranged between 21-59 years with mean \pm S.D. $40.96 \pm 12.638$ years. There was no statistically significant differences between groups where $\mathrm{P}=0.212$. Patient's sex in Group (A) showed that 27(54\%) were males and $23(46 \%)$ were females while in Group (B) 25(50\%) were males and $25(50 \%)$ were females. There was no statistically significant difference between groups where $\mathrm{P}=0.841$ (Table 1).

Table (1): Comparison between two groups as regard to patient's age (years)

\begin{tabular}{|c|c|c|c|c|c|}
\hline $\begin{array}{ll} & \text { Groups } \\
\text { Parameters }\end{array}$ & \multicolumn{2}{|c|}{$\begin{array}{c}\text { Group (A) } \\
(\mathbf{n}=50)\end{array}$} & \multicolumn{2}{|c|}{$\begin{array}{c}\text { Group (B) } \\
(\mathbf{n}=50)\end{array}$} & P-Value \\
\hline $\begin{array}{c}\text { Age: } \\
\text { Min.-Max. }\end{array}$ & \multicolumn{2}{|c|}{$20-60$} & \multirow{2}{*}{\multicolumn{2}{|c|}{$\frac{21-59}{40.96 \pm 12.638}$}} & \multirow[t]{3}{*}{0.212} \\
\hline Mean \pm S.D & \multicolumn{2}{|c|}{$43.94 \pm 12.363$} & & & \\
\hline & No. & $\%$ & No. & $\%$ & \\
\hline $\begin{array}{l}\text { Sex: } \\
\text { Males }\end{array}$ & 27 & 54 & 25 & 50 & 0.841 \\
\hline Females & 23 & 46 & 25 & 50 & \\
\hline
\end{tabular}

Patient's Cause of ESRD in Group (A) showed that the major cause of ESRD was diabetes mellitus 34(68\%) followed by hypertension $13(26 \%)$. Duration on dialysis ranged between 4-16 months with a mean of value $10.20 \pm 3.574$ months (Table 2).

Table (2): Distribution of studied cases as regard to patient's cause of ESRD and duration on dialysis

\begin{tabular}{|c|c|c|}
\hline $\begin{array}{ll}\text { Parameters } & \text { Group }(\mathrm{A})(\mathrm{n}=\mathbf{5 0}) \\
\end{array}$ & No. & $\%$ \\
\hline \multicolumn{3}{|l|}{ Causes of ESRD } \\
\hline DM & 34 & 68 \\
\hline Hypertension & 13 & 26 \\
\hline Chronic Glomerulonephritis & 3 & 6 \\
\hline \multicolumn{3}{|l|}{ Duration on dialysis years } \\
\hline Min.-Max. & \multicolumn{2}{|c|}{$4-16$} \\
\hline Mean \pm S.D & \multicolumn{2}{|c|}{$10.20 \pm 3.574$} \\
\hline
\end{tabular}

Patient's urea in Group (A) ranged between 73.57-144.99 with mean \pm S.D. $109.646 \pm 20.085$, while in Group (B) ranged between 24.39-30.50 with mean \pm S.D. 27.524 \pm 1.876 . There were statistically significant differences between groups where $\mathrm{P}<0.001$. Patient's creatinine in Group (A) ranged between 3.10-8 with mean \pm S.D. 5.902 \pm 1.633 , while in Group (B) ranged between 0.650.92 with mean \pm S.D. $0.771 \pm 0.080$. There were statistically significant differences between groups where $\mathrm{P}<0.001$ (Table 3). 
Table (3): Comparison between the two studied groups according to Kidney Function Test

\begin{tabular}{|c|c|c|c|}
\hline $\begin{array}{ll}\text { Parameters } & \text { Groups } \\
\end{array}$ & $\begin{array}{c}\text { Group }(A) \\
(\mathbf{n}=\mathbf{5 0})\end{array}$ & $\begin{array}{c}\text { Group }(B) \\
(\mathbf{n}=\mathbf{5 0})\end{array}$ & $\mathbf{P}$ \\
\hline \multicolumn{4}{|l|}{ Urea $(\mathrm{mg} / \mathrm{dL})$} \\
\hline Min.-Max. & $73.57-144.99$ & $24.39-30.50$ & \multirow{2}{*}{$<0.001$} \\
\hline Mean \pm S.D & $109.646 \pm 20.085$ & $27.524 \pm 1.876$ & \\
\hline \multicolumn{4}{|l|}{ Creatinine $(\mathrm{mg} / \mathrm{dL})$} \\
\hline Min.-Max. & $3.10-8$ & $0.65-0.92$ & \multirow{2}{*}{$<0.001$} \\
\hline Mean \pm S.D & $5.902 \pm 1.633$ & $0.771 \pm 0.080$ & \\
\hline
\end{tabular}

Patient's iron in Group (A) ranged between 28.61-133.11 with mean \pm S.D. 83.372 \pm 31.297 , while in Group (B) ranged between 62.87-169.94 with mean \pm S.D. $102.968 \pm 30.887$. There were statistically significant differences between groups where $\mathrm{P}=0.005$.

Patient's ferritin in Group (A) ranged between 159.51-539.92 with mean \pm S.D. $379.44 \pm 120.359$, while in Group (B) was ranged between 13.09-289.08 with mean \pm S.D. $347.77 \pm 58.245$. There were statistically significant differences between groups where $\mathrm{P}<0.001$.
Patient's TIBC in Group (A) ranged between 180.61-291.70 with mean \pm S.D. $239.16 \pm 35.905$, while in Group (B) ranged between 245.39-444.42 with mean \pm S.D. 3.246 \pm 0.188 . There were statistically significant differences between groups where $\mathrm{P}=0.010$.

Patient's transferrin saturation in Group (A) ranged between 11.11-53.27 with mean \pm S.D. $30.85 \pm 12.248$, while in Group (B) ranged between 25.04-35.00 with mean \pm S.D. $29.81 \pm 2.893$. There were no statistically significant differences between groups where $\mathrm{P}=0.915$ (Table 4).

Table (4): Comparison between the two studied groups according to Iron study

\begin{tabular}{|c|c|c|c|}
\hline $\begin{array}{ll}\text { Parameters } & \text { Groups } \\
\end{array}$ & $\begin{array}{c}\text { Group (A) } \\
(\mathbf{n}=50)\end{array}$ & $\begin{array}{c}\text { Group (B) } \\
(\mathbf{n}=50)\end{array}$ & $\mathbf{P}$ \\
\hline \multicolumn{4}{|l|}{ Iron $\mu \mathrm{g} / \mathrm{Dl}$} \\
\hline Min.-Max. & $28.61-133.11$ & $62.87-169.94$ & \multirow{2}{*}{0.005} \\
\hline Mean \pm S.D & $83.372 \pm 31.297$ & $102.968 \pm 30.887$ & \\
\hline \multicolumn{4}{|l|}{ Ferritin (ng/ml) } \\
\hline Min.-Max. & $159.51-539.92$ & $13.09-289.08$ & \multirow{2}{*}{$<0.001$} \\
\hline Mean \pm S.D & $379.44 \pm 120.359$ & $170.39 \pm 79.378$ & \\
\hline \multicolumn{4}{|l|}{ TIBC $\mu \mathrm{g} / \mathrm{dL}$} \\
\hline Min.-Max. & $180.61-291.70$ & $245.39-444.42$ & \multirow{2}{*}{$<0.001$} \\
\hline Mean \pm S.D & $239.16 \pm 35.905$ & $347.77 \pm 58.245$ & \\
\hline \multicolumn{4}{|l|}{ Transferrin (\%) saturation } \\
\hline Min.-Max. & $11.11-53.27$ & $25.04-35.00$ & \multirow{2}{*}{0.915} \\
\hline Mean \pm S.D & $30.85 \pm 12.248$ & $29.81 \pm 2.893$ & \\
\hline
\end{tabular}

Patient's PTH in Group (A) ranged between 70.50-95 with mean \pm S.D. 82.02 \pm 7.390 , while in Group (B) ranged between 10-64 with mean \pm S.D. $34.37 \pm 17.529$. There were statistically significant differences between groups where $\mathrm{P}<0.001$.

Patient's $\beta 2$ - microglobulin in Group (A) ranged between 76.00-109.70 with mean \pm S.D. 94.162 \pm 9.735 , while in Group (B) ranged between $0.78-3.29$ with 
mean \pm S.D. $1.956 \pm 0.704$. There were statistically significant differences between groups where $\mathrm{P}<0.001$.

Patient's EF (\%) in Group (A) ranged between 35-56 with mean \pm S.D.
44.82 \pm 6.278 , while in Group (B) ranged between 51-65 with mean \pm S.D. 57.46 \pm 4.072 . There were statistically significant differences between groups where $\mathrm{P}<0.001$ (Table 5).

Table (5): Comparison between two groups as regard to patient's PTH and $\beta 2-$ macroglobulin

\begin{tabular}{|c|c|c|c|}
\hline $\begin{array}{l}\text { Groups } \\
\text { Parameters }\end{array}$ & $\begin{array}{c}\text { Group (A) } \\
(\mathbf{n}=50)\end{array}$ & $\begin{array}{c}\text { Group (B) } \\
(\mathbf{n}=50)\end{array}$ & P-Value \\
\hline \multicolumn{4}{|l|}{ PTH $(\mathrm{pg} / \mathrm{mL})$} \\
\hline Min.-Max. & $70.50-95$ & $10-64$ & \multirow{2}{*}{$<0.001$} \\
\hline Mean \pm S.D & $82.02 \pm 7.390$ & $34.37 \pm 17.529$ & \\
\hline \multicolumn{4}{|c|}{ B2-microglobulin mg/L } \\
\hline Min.-Max. & $76.00-109.70$ & $0.78-3.29$ & \multirow{2}{*}{$<0.001$} \\
\hline Mean \pm S.D & $94.162 \pm 9.735$ & $1.956 \pm 0.704$ & \\
\hline \multicolumn{4}{|l|}{ EF \% } \\
\hline Min.-Max. & $35-56$ & $51-65$ & \multirow{2}{*}{$<0.001$} \\
\hline Mean \pm S.D & $44.82 \pm 6.278$ & $57.46 \pm 4.072$ & \\
\hline
\end{tabular}

Patient's LVMI in Group (A) ranged between 111.87-131.59 with mean \pm S.D. $123.41 \pm 5.675$, while in Group (B) ranged between 82.02-104.84 with mean \pm S.D. $91.63 \pm 7.236$. There were statistically significant differences between groups where $\mathrm{P}<0.001$.

Patient's Intraventricular septal thickness in Group (A) ranged between 1.17-2 with mean \pm S.D. $1.62 \pm 0.267$, while in Group (B) ranged between 0.40-1.13 with mean \pm S.D. $0.775 \pm 0.225$. There were statistically significant differences between groups where $\mathrm{P}<0.001$.
Patient's LVEDD in Group (A) ranged between 5.94-7.56 with mean \pm S.D. $6.79 \pm 0.505$, while in Group (B) ranged between 3.27-5.25 with mean \pm S.D. $4.25 \pm 0.571$. There were statistically significant differences between groups where $\mathrm{P}<0.001$.

Patient's LVESD in Group (A) ranged between 4.80-5.73 with mean \pm S.D. $5.34 \pm 0.250$, while in Group (B) ranged between 2.87-3.65 with mean \pm S.D. $3.27 \pm 0.243$. There were no statistically significant differences between groups where $\mathrm{P}<0.001$ (Table 6). 
Table (6): Comparison between the two studied groups according to echocardiography

\begin{tabular}{|c|c|c|c|}
\hline $\begin{array}{ll}\text { Parameters } & \text { Groups } \\
\end{array}$ & $\begin{array}{c}\text { Group (A) } \\
(\mathbf{n}=50)\end{array}$ & $\begin{array}{c}\text { Group }(B) \\
(\mathbf{n}=50)\end{array}$ & $\mathbf{P}$ \\
\hline \multicolumn{4}{|l|}{ LVMI $\mathrm{g} / \mathrm{m}^{2}$} \\
\hline Min.-Max. & $111.87-131.59$ & $82.02-104.84$ & \multirow[b]{2}{*}{$<0.001$} \\
\hline Mean \pm S.D & $123.41 \pm 5.675$ & $91.63 \pm 7.236$ & \\
\hline \multicolumn{4}{|c|}{ Intraventricular septal thickness, $\mathrm{cm}$} \\
\hline Min.-Max. & $1.17-2$ & $0.40-1.13$ & \multirow{2}{*}{$<0.001$} \\
\hline Mean \pm S.D & $1.62 \pm 0.267$ & $0.775 \pm 0.225$ & \\
\hline \multicolumn{4}{|l|}{ LVEDD, $\mathrm{cm}$} \\
\hline Min.-Max. & $5.94-7.56$ & $3.27-5.25$ & \multirow{2}{*}{$<0.001$} \\
\hline Mean \pm S.D & $6.79 \pm 0.505$ & $4.25 \pm 0.571$ & \\
\hline \multicolumn{4}{|l|}{ LVESD, cm } \\
\hline Min.-Max. & $4.80-5.73$ & $2.87-3.65$ & \multirow{2}{*}{$<0.001$} \\
\hline Mean \pm S.D & $5.34 \pm 0.250$ & $3.27 \pm 0.243$ & \\
\hline
\end{tabular}

There was a significant correlation between plasma B2M level and echocardiographic data in patients with CKD (Table 7).

Table (7): Correlation between Plasma B2M Level and Echocardiographic data in patients with CKD

\begin{tabular}{|l|c|c|}
\hline Values & r & P value \\
\hline Parameters & -0.622 & $<0.001$ \\
\hline LVMI, g/m2 & 0.438 & $<0.001$ \\
\hline Interventricular septal thickness, cm & 0.330 & 0.004 \\
\hline LVEDD, cm & 0.41 & 0.021 \\
\hline LVESD, cm & 0.319 & 0.024 \\
\hline
\end{tabular}

\section{DISCUSSION}

As regard sociodemographic data, age in Group (A) ranged between 20-60 years Group (B) ranged between 21-59 years. There were no statistically significant differences between groups where $\mathrm{P}=0.212$. Patient's sexes in Group (A) $54 \%$ were male and $46 \%$ were females while in Group (B) $50 \%$ were male and $50 \%$ were females. There were no statistically significant differences between groups. There were no statistically significant differences between groups regarding working status.
The accumulation of middle molecular weight solutes, such as beta-2 microglobulin (b2M), is toxic to various body tissues and has been associated with adverse cardiovascular and infectious outcomes among patients with end-stage renal disease (ESRD) (Cheung et al., 2010).

In the present study, that the major cause of ESRD in Group (A) was diabetes mellitus, hypertension and chronic glomerolsclerosis. Duration on dialysis ranged between 4-16 months.

Our results were in line with study of Mumtaz et al. (2010) as they reported that 
the main causes of ESRD in the studied group were diabetes mellitus followed by hypertension and the mean duration on dialysis was 13.82 months with a range of three to sixteen months.

Those results were in line with study of Mumtaz et al. (2010) and Dung et al. (2019), the present study showed that there were statistically significant differences between groups iron, ferritin and TIBC and PTH.

The current study showed there was $\beta 2-$ microglobulin statistically significant difference between groups.

Our results were in agreement with study of Cheung et al. (2010), Mumtaz et al. (2010), Kim et al. (2011), Sedighi et al. (2015) and Malik et al. (2018) as they reported that mean plasma B2M level was significantly higher in patients with CKD than control group.

The major reason for such a high level of $32-\mathrm{m}$ in the previous study was that the dialyzer used for HD in their patients was of the low-flux type. As $32-\mathrm{m}$ is a middle molecule of molecular weight of 12000 Da, conventional, low-flux dialyzers do not clear these molecules which lead to accumulation of this silent killer in the body. Financial constraints are the major reason for using low-flux dialyzers in their patients. The cost of dialysis when lowflux dialyzers are used is about US Dollars 400 as against the cost for using high-flux HF dialyzers, which is about 50 US Dollars more. This factor is the major reason for using low-flux dialyzers and accumulation of $32-\mathrm{m}$ in these patients (Sedighi et al., 2015).

Liabeuf et al. (2012) confirms that plasma B2M levels are elevated in CKD patients and that these levels progressively increase with decreasing GFR and peak in hemodialysis patients. More interestingly, B2M levels were independently associated with overall and cardiovascular mortality and cardiovascular events in the entire cohort and with cardiovascular events in predialysis patients. Moreover, they show that circulating $\mathrm{B} 2 \mathrm{M}$ is a better predictor of overall and cardiovascular mortality for the whole cohort and of cardiovascular events for predialysis patients, compared with well-established factors associated with outcomes in this population, including eGFR, inflammation biomarkers, and others factors included in a propensity score.

The present study showed that EF (\%) was statistically significant differences between groups. Patient's LVMI intraventricular septal thickness there were statistically significant differences between groups.

LVEDD showed statistically significant differences between groups, no statistically significant difference in LVESD between groups.

Our results were supported by study of Amighi et al. (2011) who showed a strong association between serum B2M level and cardiovascular events in patients with prevalent asymptomatic carotid atherosclerosis, with comorbidity severity similar to patients with CKD, even after adjustment for CRP and GFR. Cheung et al. (2013) reported serum B2M level as a novel risk marker for all-cause and cardiovascular mortality in patients with diabetes mellitus, regardless of renal function. Shinkai et al. (2012) suggested that, in old age population, the predictive value of plasma B2M level was superior 
to other established prognostic factors for mortality such as GFR, cystatin C, and CRP. Furthermore, Wu et al. (2017) found that in those with CKD, serum B2M was more sensitive than creatinine in predicting CVEs and MIA syndrome.

Regarding Dung et al. (2019), during the follow-up period of 5 years, there were 75 all-cause deaths (23.0\%). KaplanMeier analysis revealed that all-cause mortality in the higher $\beta 2-\mathrm{M}$ group was significantly higher compared to that in the lower $\beta 2-M$ groups. Serum $\beta 2-M$ level was a significant predictor for all-cause mortality.

The role of $\mathrm{B} 2 \mathrm{M}$ in patients with $\mathrm{CKD}$ is unclear. Uremic milieu has a harmful effect on the cardiovascular system. In an in vitro study, high serum B2M and indole-3-acetic acid levels were with low CD34+ and CD133+ endothelial progenitor cells that contribute to vessel repair and neovascularization (JourdeChiche et al., 2011). Moreover, other uremic toxins such as P-cresyl sulfate and guanidine compounds might disturb endothelial proliferation and vascular repair mechanism (Schepers et al., 2010).

\section{CONCLUSION}

Plasma B2M level was significantly and directly correlated with some cardiac performance factors such as LVMI, LVEDD, and LVESD. It was also significantly and inversely associated with GFR, albumin and $\mathrm{Hb}$. Thus, B2M might have an important role in the development of cardiovascular diseases in patients on regular hemodialysis.

\section{REFERENCES}

1. Amighi J, Hoke M, Mlekusch W, Schlager O, Exner M, Haumer M, Pernicka E,
Koppensteiner R, Minar E, Rumpold H, Schillinger $M$ and Wagner O. (2011): Beta 2 microglobulin and the risk for cardiovascular events in patients with asymptomatic carotid atherosclerosis. Stroke, 42(7):1826-33.

2. Cheung AK, Greene T and Leypoldt JK. (2010): Association between serum b2microglobulin level and infectious mortality in hemodialysis patients. Clin J Am Soc Nephrol., 3: 69-77.

3. Cheung CL, Lam KS and Cheung BM. (2013): Serum $\beta-2$ microglobulin predicts mortality in people with diabetes. Eur J Endocrinol., 169(1):1-7.

4. Dung NH, Kien NT, Hai NT, Cuong PT, Huong NT, Quyen DB and Toan PQ. (2019): Measuring serum beta2-microglobulin to predict long-term mortality in hemodialysis patients using low-flux dialyzer reuse. Therapeutics and Clinical Risk Management, 15: 839-43.

5. Fatima T, Afzal A and Ashraf, S. (2018): Chronic kidney disease; acute intradialytic complications in chronic kidney disease patients on hemodialysis. Professional Medical Journal, 25(6):136- 142.

6. Hoang VL, Green T and Bonner A. (2019): Informal caregivers of people undergoing haemodialysis: Associations between activities and burden. Journal of Renal Care, 45(3): 151158.

7. Jasim AA, Mohammed AA and Ibrahim AA. (2019): Functional Analysis of Beta 2 Microglobulin Protein in Patients with Prostate Cancer Using Bioinformatics Methods. Indian Journal of Public Health Research and Development, 10(3): 519-523.

8. Jeloka T, Mathur G, Kaur R, Kohli R, Singh NP and Rizvi SN. (2010): $\beta 2$ Microglobulin in chronic renal failure and effect of different dialyzer membrane on its clearance. Indian $\mathrm{J}$ Nephrol., 11:160-4.

9. Jourde-Chiche N, Dou L, Sabatier F, Calaf R, Cerini C, Robert S, Camoin-Jau L, Charpiot $P$, Argiles A, Dignat-George $F$ and Brunet P (2011): Levels of circulating endothelial progenitor cells are related to uremic toxins and vascular injury in 


\section{MOHAMED FATHY AL-MSHALY et al.,}

hemodialysis patients. J ThrombHaemost., 7(9):1576-84.

10. Kim KM, Kim SS, Kim H, Koo T, Im EY and Kim SB. (2011): Higher serum beta2microglobulin levels are associated with better survival in chronic hemodialysis patients: a reverse epidemiology. Clin Nephrol., 75(5):458-65.

11. Liabeuf S, Lenglet A, Desjardins L, Neirynck N, Glorieux $G$ and Lemke HD. (2012): Plasma beta- 2 microglobulin is associated with cardiovascular disease in uremic patients. Kidney International, 82(12): 1297-1303.

12. Malik AR, Grover N, Singh S, Singh $N$ and Singh P. (2018): Evaluation of Serum Beta 2 Microglobulin Levels in Oral Leukoplakia Patients. Journal of Advanced Medical and Dental Sciences Research, 6(10): 16-22.

13. Mumtaz A, Anees M, Bilal $M$ and Ibrahim M. (2010): Beta-2 microglobulin levels in hemodialysis patients. Saudi Journal of Kidney Diseases and Transplantation, 21(4): 701-6.

14. Schepers E, Glorieux G, Dou L, Cerini C, Gayrard N, Louvet L, Maugard C, Preus P and Rodriguez-Ortiz M. (2010): Guanidino compounds as cause of cardiovascular damage in chronic kidney disease: an in vitro evaluation. Blood Purif., 30(4):277-87.

15. Sedighi O, Abediankenari S and Omranifar B. (2015): Association between plasma Beta-2 microglobulin level and cardiac performance in patients with chronic kidney disease. NephroUrology Monthly, 7(1): 15-21.

16. Shinkai S, Chaves PH, Fujiwara Y, Watanabe S, Shibata $H$, Yoshida $H$ and Suzuki T. (2012): Beta2-microglobulin for risk stratification of total mortality in the elderly population: comparison with cystatin $\mathrm{C}$ and $\mathrm{C}$ reactive protein. Arch Intern Med., 168(2):2006.

17. Singh MN, Lal A, Poddar CK and Ejaz SK. (2017): Comparative evaluation of ELISA and rapid screening techniques for the diagnosis of $\mathrm{HCV}$ in haemodialysis patients in tertiary care hospital, South Bihar, India. Journal of Evolution of Medical and Dental Sciences, 6(93): 100-105.

18. Wong J, Sridharan S, Berdeprado J, Vilar $E$, Viljoen A, Wellsted $D$ and Farrington $K$. (2016): Predicting residual kidney function in hemodialysis patients using serum $\beta$-trace protein and $\beta 2$-microglobulin. Kidney International, 89(5): 1090-1098.

19. Wu HC, Lee LC and Wang WJ. (2017): Associations among serum beta 2 microglobulin, malnutrition, inflammation, and advanced cardiovascular event in patients with chronic kidney disease. Journal of Clinical Laboratory Analysis, 31(3): 22056-62. 


\section{العلاقة بين مستوى الميكرو غلوبيولين بيتا 2 وأداء القلب فى مرضى الإئ

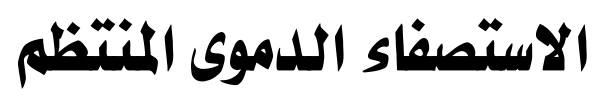

محمد فتحى المشالى, صفوت فراج أحمد, محمد سعيد الشوربجي*, السيا محمد راشد, محمد أحمد مسعد** ت

أقسام الطب الباطني وأمراض الكلى والباثولوجيا الإكلينيكيةث* وأمراض القلب**، كلية الطب، جامعة الأزهر

E-mail: $\underline{\text { mohamedfathy888@ gmail.com }}$

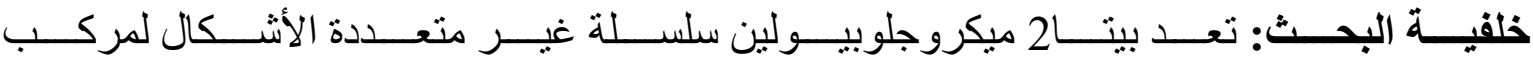

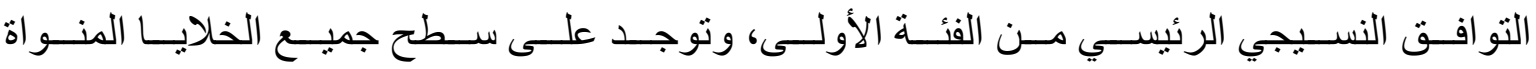

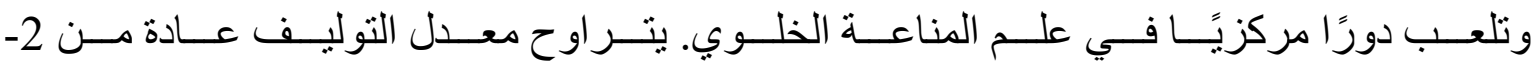

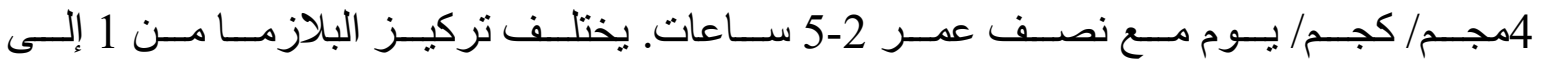

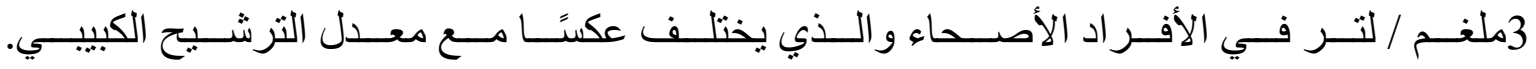

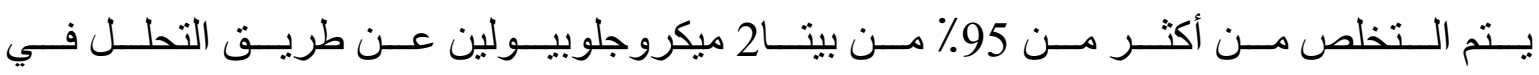

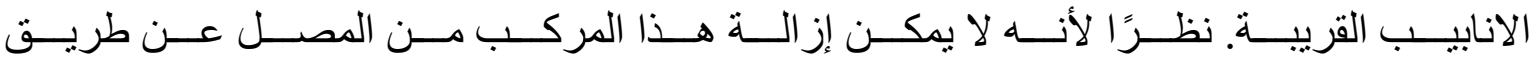

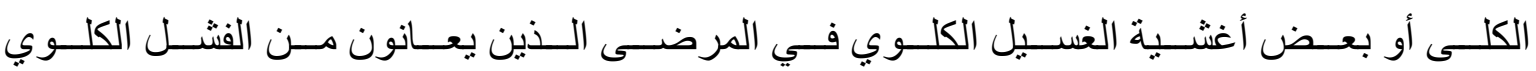

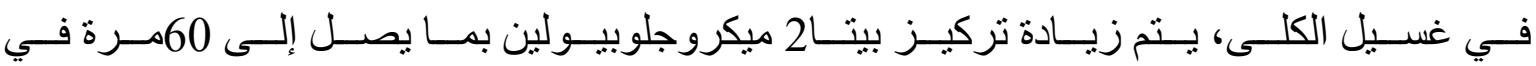
المرضى الذين يعانون من مرض كلوي في المرحلة النهائية.

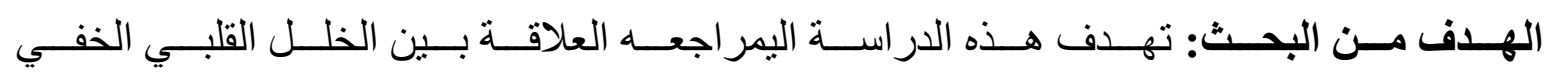

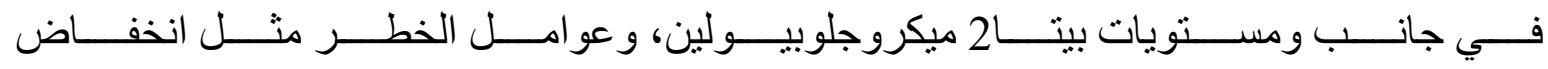
مستويات الهيمو غلوبين، و الثيخوخة على الجانب الآخر.

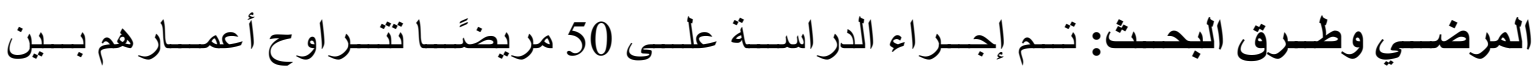

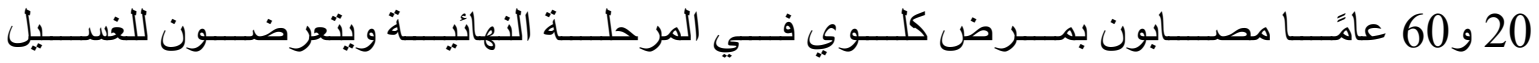

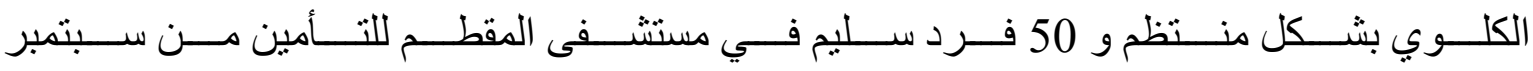

$$
2019 \text { حتى مارس } 2020 .
$$

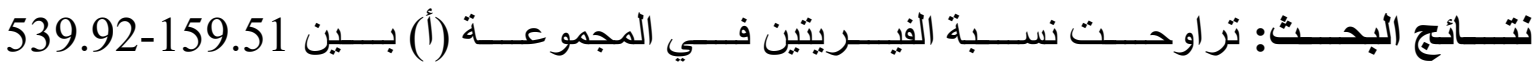

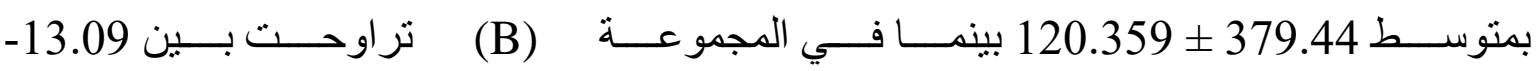




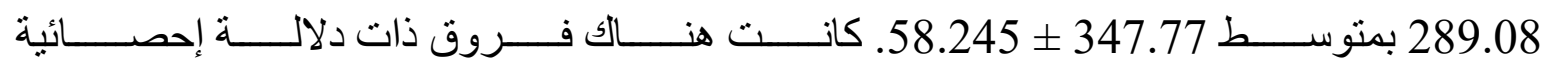

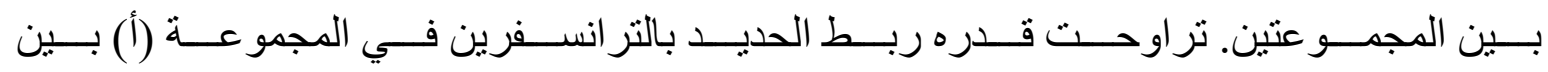

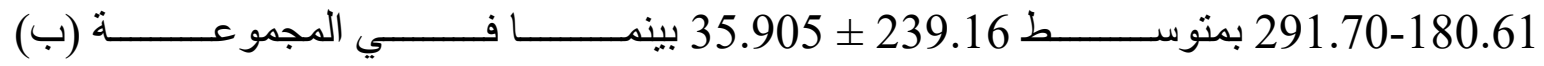

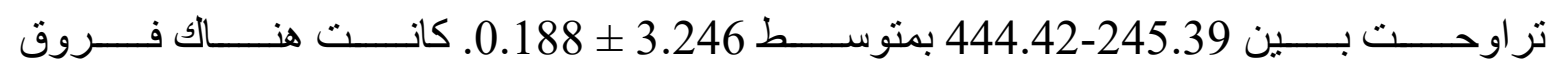

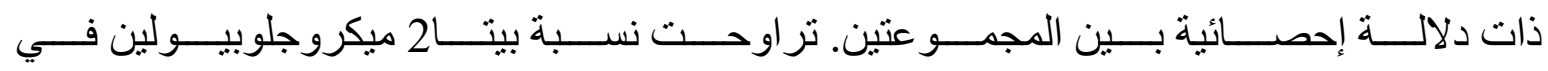

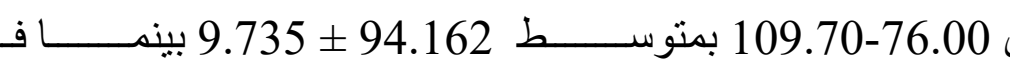

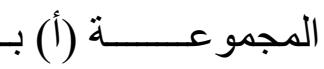

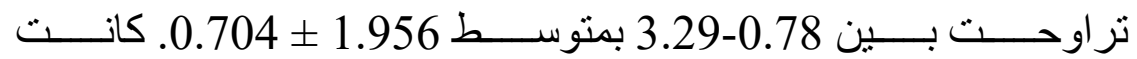

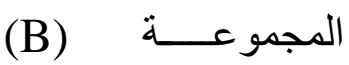

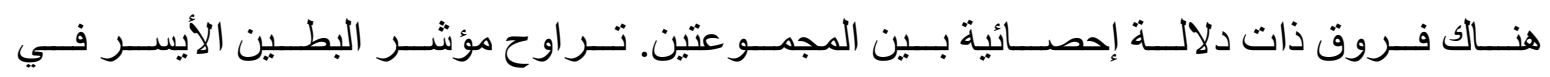

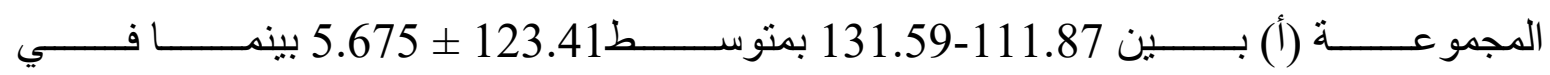

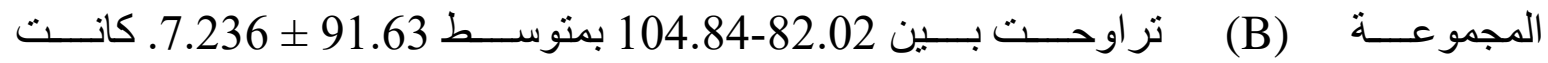

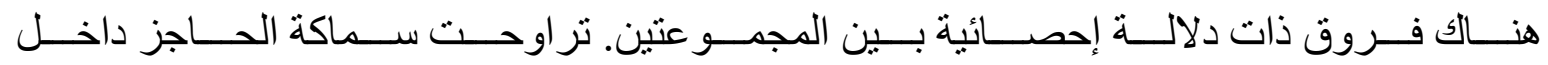

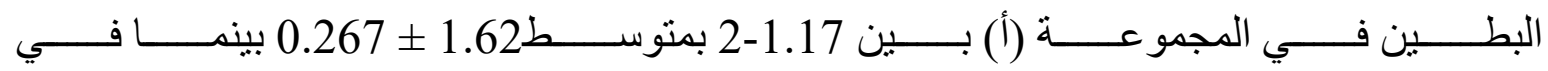

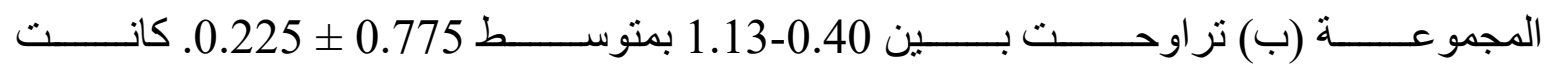

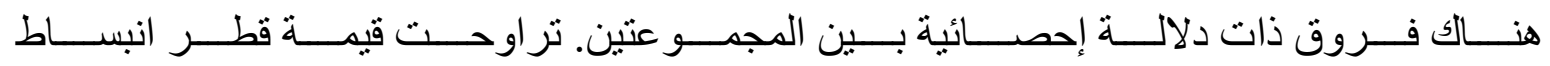

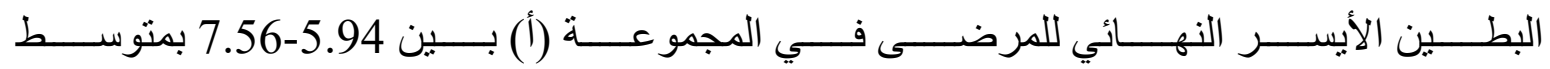

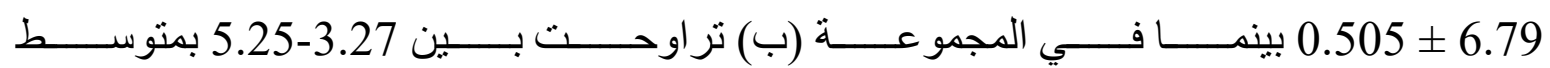

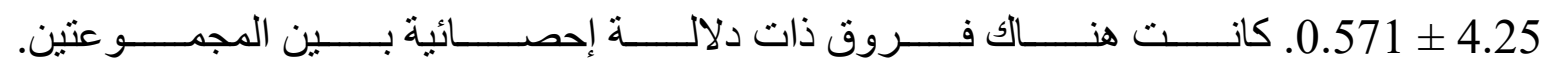
تر اوحـــ قيمــة قطــر انقبـاض البطـين الأيســر النهــائي للمرضــى فـي المجموعــة (أ) بــين

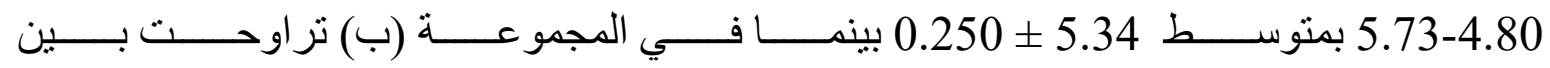

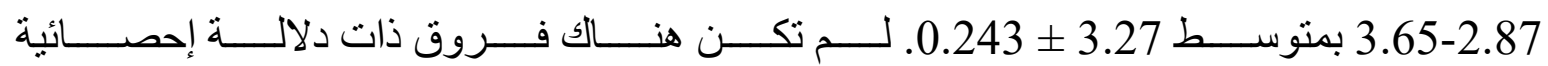
بين المجمو عتين.

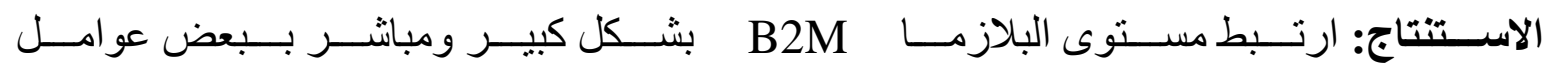

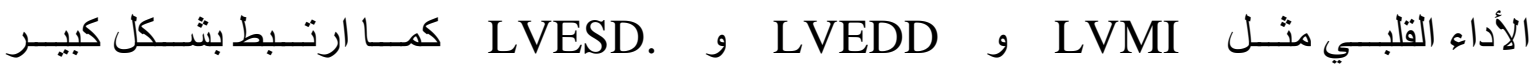
و عكسي مع GFR و الألبومين وGb.

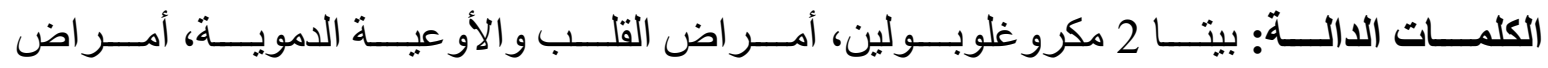
الكلى المزمنة، الوفيات، السموم البوليسية، غسيل الكلى. 